\title{
CONTEMPORARY UKRAINIAN LITERATURE FOR CHILDREN AND YOUTH IN THE CONTEXT OF MULTICULTURALISM AS AN EDUCATIONAL PRACTICE
}

\author{
TETIANA KACHAK, TETYANA BLYZNYUK
}

\begin{abstract}
The article outlines the problem of relevance of multiculturalism in Ukrainian society and educational practice of the modern Ukrainian school. The authors analyze the artistic works by Oksana Lushchevska, addressed to young readers, representing the coexistence of various forms of cultural life, highlighting the problem of preserving one's own and perceiving another cultural identity, tolerant interaction of representatives of various ethnic groups. Simultaneously, the novel by American writer Rainbow Rowell focused on negative phenomena of interethnic interaction, but offered readers an interesting and multifunctional artistic text in terms of receptive poetics and aesthetics. Considered in the paper works can be an effective means of multicultural education and upbringing of schoolchildren.
\end{abstract}

Keywords: literature for children and youth, multiculturalism, multicultural education, interaction of cultures.

\section{INTRODUCTION}

Modern literature for children is an artistic and aesthetic, socio-cultural phenomenon, an effective means of development and socialization of a young person. Artistic texts not only reflect the problems of man and society, but also propagate certain values, demonstrate patterns of behavior that affect the formation of the worldview and life position of the younger generation. Books for children become especially important when it comes to moral and ethical upbringing, national identity, tolerance in the modern multi-ethnic space. New standards of general and higher education, curricula oriented to the formation of a competent personality, which could fully function in a modern multicultural society; show respect and tolerance for the cultural identity of other people, and at the same time maintain their own national identity. Search for effective approaches and means of multicultural direction of education of schoolchildren is an urgent problem of the modern educational process.

The purpose of this research is to consider works of art intended for young readers representing the coexistence of different forms of cultural life, covering the problem of preserving one's own and the perception of others' cultural identity, interaction of representatives of various ethnic groups, and can be an effective means of multicultural education.

The works of foreign and domestic literary critics (U. Baran, V. Vzdulska, T. Kachak, V. Kyzylova, K. Leshnik-Oberstein, L. Matsevo-Bekerskaya, L. Ovdiychuk, E. Ogar, M. Slavova, P. Hunt and etc.) 
who study the poetics of artistic works for children and young people, scientists studying the problem of multiculturalism (S. Drozhin, S. Zhyzhek, O. Kalakura, M. Kozlovets, M. Mykhailova, R. de Codiac, etc.) including in the educational-educational branch (A. Perotti, M. Ragozin etc.) became the theoretical and methodological basis of our research.

Ronan de Codiak suggests understanding the concept and practice of multiculturalism through the prism of three waves of identity [16]. Slava Zhyzhek considers multiculturalism as a response to globalization, as an ideology, the essence of which is exploitation and destruction of manifestations of individuality [13]. In the context of our intelligence we use the usual definition of the concept: multiculturalism is a social phenomenon, ideology, discourse, which involves the interaction and coexistence of different cultures within a single society. The strategy of multiculturalism in the American and Western countries, which is widespread in connection with the intensification of migration processes, globalization, is becoming increasingly important in Ukrainian society.

\section{RESULTS AND DisCUSSION}

Given the fact that multiculturalism is considered to be "one of the ways to overcome tension in multicultural countries and options for activating the democratization process" [1, p. 96], the problem of the formation of multicultural values in the younger generation, as well as the search for effective means of their multicultural education is relevant and timely. Multicultural education is one of the forms of practical policy of multiculturalism. Its components are training, education and informational and educational activities. Multicultural learning involves the students learning knowledge, skills and abilities of the history of peoples, ethnopolitics, intercultural communication, cultural studies, ethnic psychology, linguistics. The curriculum for primary school provides for the study only certain information on the content of multicultural education. The main tasks of forming socio-cultural competence of the junior pupil are realized mainly at the lessons of Literary reading, Foreign languages, subjects "I am in the world", "Art". In the process of preparing future teachers - students of the specialty "Primary Education", implementation of the content and objectives of multicultural education is provided by the subjects of the language-literary cycle ("Foreign Language", "Children's Literature", "Foreign Children's Literature", "Country Studies", "English Literature", "Modern English Literature" etc.). Multicultural learning in the practice of the Ukrainian school cannot be considered a complete process, as it is rather one of the aspects of implementation of the content in socio-cultural line and formation of socio-cultural competence of schoolchildren. "The sociocultural content line is a means of mastering national, universal cultural and spiritual values, norms governing relations between generations, sexes, nations, contribute to the aesthetic and moral and ethical development of the individual, its organic entry into society" [11]. In 2017, with the allocation of cross-cutting content lines as a means of integrating key and general-purpose competencies, as socially significant subthemes, socio-cultural competence is considered as one of the components of the cross-cutting content line "Civil Responsibility". Priority tasks in implementation of this content line are "the formation of a responsible member of the community and society, which understands the principles and mechanisms of its functioning, as well as the importance of the national initiative" [2]; as well as developing the students' ability to interact with other people in a multicultural society; form ation of the spiritual world of students, valuable ideological ideas, universal values, etc.

Education of a multicultural person involves the formation of citizenship, tolerance, cultural pluralism. The problem of tolerance, as noted by M. Kozlovets and M. Mykhailova, became acute in the connection with the problem of consolidation in multiethnic societies. "In this context, tolerance is the unity in diversity, respect, perception and understanding of a huge number of cultures, forms of selfexpression and self-expression of the human person" [5, p. 469].

Alongside with the desire for tolerant perception and interaction of cultures, there is a threat of erosion of national identity. Proponents of multiculturalism argue that a multicultural society involves preserving by a personality its identity, despite the effects of other cultures. Focusing on this principle, in 2017, a new Law on Education was adopted in Ukraine. It stipulates that "the language of the 
educational process in educational institutions is the state language", but at the same time, persons belonging to indigenous peoples of Ukraine are guaranteed the right to study in communal institutions of preschool and general secondary education along with the state language in the language of the respective indigenous people [6]. Representatives of ethnic minorities have the right to study in their native languages, but it is also necessary to study Ukrainian as a state language, to learn the culture of the Ukrainian people. This enables them to successfully integrate into society, simultaneously belong to several cultures, preserving their own ethno-cultural, ethnic, mental values and other specific nationally-determined attributes. This phenomenon is one of the aspects of normative attributes (along with descriptive - the presence of ethno-cultural and linguistic diversity) of a multicultural society.

The problems of multiculturalism are particularly considered in the philosophical, educational and literary field. A multicultural approach to studying Literature for children and Reading is practiced by foreign researchers Joh C. Stott, Nansy Larrick, Daniel Hade, and others.

Modern literature for children demonstrates various examples of multicultural interaction, which are realized through the components of the poetics of artistic work: subject, plot, images, hero's behavior, language and narration. If foreign writers openly raise questions of multiculturalism for more than half a century, Ukrainian authors often address this problem in the first place, along with the central storyline, cover certain episodes of interaction between representatives of different nations, emphasize the elements of their culture, use a set of stereotypes (national symbols, mental characteristics), consider national identification and perception of others. Multicultural elements are noted in the historical prose by Volodymyr Rutkivsky (tetralogy "Dzury") and Yaroslav Yarish ("Samiylo"), realistic prose by Stepan Protsyuk ("Vitrolomy"), stories by Dzvinka Matiiash ("Martha from St. Nicholas Street"), Zirka Menzatyuk ("How I Destroyed the Empire"), adventure prose by Oleksandr Gavrosh ("The Incredible Adventures of Ivan Syla") and Oleksiy Bilobrov ("On the Boundary of Opportunity"). Among the Ukrainian writers, the brightest examples of literature, which fully expands the multicultural discourse, is presented by Oksana Lushchevska, a writer, translator, literary critic and critic of literature for children. [3, p. 322-324].

In the stories "Best Friends" and "Friends for Correspondence", Oksana Lushchevska touches upon the problems of growing up, children's emotions, shows the relationships of children with different mental worldviews, and also displays cultures and traditions of different peoples. Communication (direct and in the letters) of the Ukrainian girl Ksenia with Eric from the overseas, friendship with children of different nationalities in the English-language camp, change her attitude toward herself and to the world, her views on culture and spiritual development of the individual. The writer shows that the process of linguistic interaction is closely connected with cultural, historical, social, psychological and other factors, and the interrelations of children in the camp are highlighted as a model of multiculturalism. In the section "Family Fire" [7, p. 107-118], the author offers readers a closer acquaintance with the heroes and their cultures, contains stories from representatives of many countries of the world. Yori tells legends and stories of South Africa, presents girls adornments made of various grains and herbs. Catalina shares an old recipe of Mexican cuisine "Nopal Grande". The girl from Greece, Ilona tells a story about Mr. Lazarus and dragons. Irish Lolly distributed amulets and explained that they symbolized beliefs of her people. Australian Keli gave all the toys - koalas, which are purely Australian exotic animals. Ukrainian schoolgirl Ksenia and the curator of the group Daria sang the Ukrainian song to the audience. Using the method of "text in the text", the writer creates a mosaic of ideas about different cultures and peoples. The author highlighted the multiculturalism and blurriness of national traditions in Australia and the United States ("... Because it's often said that Australia has no history, no traditions, no legends, why is it? They say that everything is brought in by other cultures. So it turns out that our traditions are actually, collected from your traditions... Absolutely, as in America!" [8, p. 115]). Valentyna Vzdulska in the article "Intercultural interaction as a subject in the modern Ukrainian book" calls the work of $O$. Lushchevska "multiculturalism without secret thoughts" and states: "Children demonstrate exceptional and sometimes incredible readiness and openness to communication and understanding, awareness of the multifaceted world cultures and almost idealized freedom from prejudice" [12]. 
The receptive-aesthetic value of such books increases when "multicultural reading" occurs. This is stated in the article "Reading Multicultural" by Daniel Hade [14]. The scientist distinguishes reading with educational purpose and multicultural reading. "Multiculturalism implies an understanding of three main aspects: criticism of the West ideology (Eurocentrism); challenge of coexistence in the world of differences and peculiarities between people of different races and cultures; a reform movement based on equality and justice. According to Hade, we, adults, have a good faith test of how we teach children to read. After all, reading depends on cultural and social views, and we must understand that stereotypes in the literature for children continue to form stereotypes in their outlook. Of course, stereotypes cannot be overcome quickly" [14]. Oksana Lushchevska is convinced that when reading multiculturalism, we see how each culture is associated with a certain set of stereotypes. Such stereotypes are also reflected in her story "Friends by Correspondence".

Against the background of the texts by V. Rutkivsky and O. Bilobrov (who use romantic myth and stereotypes, arguments of affinity and opposition to other countries), the novel "Friends by Correspondence" testifies that Oksana Lushchevska "deliberately distances itself from such oppositions and ideological assessments. Her text as compared with the other seems most tolerant in the multicultural context" [9]. And this principle of tolerance, when the dichotomy "self-stranger" is transformed into interaction and combination of cultures, mental attributes, ideological positions, is characteristic of the entire work of the writer.

Two worlds, two cultures, two spaces - one's and another's - are the basis of the story "Another House". In this work, multiculturalism as one of the elements of artistic consciousness, the linguistic personality of the writer complements the transcultural intentions. Oksana Lushchevska violates the problem of emigration, parents and children, maturation, and at the same time perception of another culture, the adaptation of man in a multi-ethnic socio-cultural space. The story in diary form and confessional manner is on behalf of the adolescents Polia and Artem. Children try to understand the mother's behavior, whowent to America, but it is very difficult for them to do so. They understand that "mother has changed in another country. Mom has changed in another house". Polia was terribly indignant when the teacher called Mother an emigrant and pointed out the facts that denied it: compared the depicted in the picture by Marta Volter "Entrance. Just from the ship. Ellis Island" emigrants with the fate of their mother, explained the mother's deed. "She did not have to wander, like those people in the picture. Her life line is a slowly flowing river. Mum traveled to the United States, because there was an opportunity to show the world exhibition. She also goes in for didn't marry, because she didn't want it so much. The chosen place of residence is the city of Pittsburgh, which she was terribly pleased with. This city grew up among the mountain slopes. Here and there it was crossed by bridges that led to anything but heart. Mom says there is a bridge similar to our Moscow one, which we call the bridge of life. Mom calls the same way one of the Pittsburgh bridges. She likes it so much. It is better for her" [8, p. 45]. The bridge appears in the work repeatedly, it is endowed with profound meaning and symbolic meaning: it prom pts awareness of the connection between relatives, despite the geographical distance of their place of residence. The function of the bridge is to unite people, nations and cultures.

Oksana Lushchevska now lives in the United States. She demonstrates a practical example of multiculturalism through her creativity, translation and social activities. In her creative work - bilingual books, written simultaneously in Ukrainian and English: "Letters to the War. Children Write to Soldiers", "Mr. Kotsky, Mira and the Sea". For these books, the writer selects themes that are understandable to children and are inherent in different cultures. These editions confirm that bilingualism is one of the most characteristic features of the linguistic personality and multiculturalism as an ideological position of Oksana Lushchevska.

Oksana Lushchevska considers the work of children's writers, the peculiarities of literature for children, the promotion and practice of children's reading at the intersection of national cultures. Multiculturalism as a social phenomenon not only becomes the object of the image in her artistic texts, but is endorsed in the books of other authors. Analyzing the story by O. Bilobrov "On the Boundary of 
Opportunity", O. Lushchevska notes that the story "is able to teach young people many things, and above all other cultures of other peoples and respect for their traditions and everyday life".

At the level of subjects and issues, axiology and linguistic-narrative structures of texts, transculture as a way of being an artist is manifested, characterized by going beyond the boundaries of national culture, ethnic identity, artistic and literary tradition, and linguistic and value determinations. If the concept of multiculturalism involves value equality and self-sufficiency of different cultures, the concept of transculture implies their openness and interaction. Here, the principle of nondifferentiation, and the interference, "scattering" of the symbolic values of one culture in the field of other cultures, operates. There is diffusion of the original cultural identities of the individual as the individual crosses the boundaries of different cultures and assimilates them.

Consequently, understanding of the creative personality of Oksana Lushchevska in the linguocultural perspective is based on the analysis of ontological interrelated triadity "language consciousness - culture". On the example of this writer's works, we are convinced that only by integrating into another culture, having its own experience of experiencing problems of representatives of national minorities, emigrants, the authors go through issues of intercultural interaction, integration and preservation of national identity.

The works of Oksana Lushchevska demonstrate the tolerance and constructive interaction of cultures, representatives of different nations. But in multiethnic societies there is also a destructive interaction, intolerance towards representatives of other nationalities, and to emigrants. An illustrative example of artistic comprehension of the topic of co-habitation of representatives of different cultures is raised in the bestseller of the American writer Rainbow Rowell "Eleanor and Park". Here, the problem of another, outsidering in the student community is connected both with the attitude of society to representatives of other nationalities, as well as the problems of socialization of the individual, social inequality, domestic violence. Park is the son of an American and Korean, who is only partially undergoing a boom, and the reason for this is most often the Asian appearance and behavior. However, it is not only that the father is an American but also a loving and friendly family that has its own traditions and values. He does not feel lonely, unlike Eleanor. A girl is abused at school, humiliated by her stepfather. She was ashamed of herself, could not talk about her family and living conditions. The author stresses: "The neighbors could hate Eleanor for stinginess and strangeness, but nobody despised her for having an incom plete family and a poor accomodation. Here all were like this". [15, p. 169-170].

A very successful writer shows two contrasting models of the family. Almost the ideal family of Park, where the house is dominated by love and harmony, comfort and prosperity looks very happy against the background of Eleanor's family. Her mother is getting married a second time. Father is not interested in own children, and his stepfather Richie is a drunkard and despot. One day he drove Eleanor from the house and that year he lived with his mother's girlfriend. He was afraid of all the children, but most of all he tormented Eleanor, persecuted and insulted her. This is a typical disadvantaged family, where "there is no place for teens". Mother silently endured his beatings and rudeness. They lived in a small house, where five children of different ages shared a tiny room. Eleanor did not have its own space, normal clothes, the ability to wash properly. She did not even have a toothbrush. She was ashamed to tell Park about it. Not every author dares to speak so openly with adolescents and so to disclose topics of social inequality, domestic violence.

Park's mother accepted Eleanor only after seeing her with her younger brothers and sisters in the store and realized that she was from a large family. Memories of own childhood in such a family, where they always lack all, excited so much that her attitude to Eleanor changed dramatically. The father of a teenager supported his son and did everything to make him a real man, not a loser. In his image, the writer shows such an important understanding of the father and son as through the behavior and attitude it is worthwhile to teach the child to live.

By this novel, Rainbow Rowell, also em phasizes the problem of national identity and authenticity, and overcoming racism. This aspect of the American literature for children has been developing since the 1960s: "In 1965, scientist Nancy Larrick wrote an article titled "The All-White World of Children's Books", which first covered issues of racial affiliation in works for children. Since the 1980', 
multiculturalism in literature has become an extremely topical issue. Today, racial, class, and gender aspects of books for children are widely studied in the United States. Literature for children is perceived as serving not only the reflection of other cultures, but also primarily forms selfunderstanding and self-identification through the category of the Other" [9].

The story of Eleanor and Park, which unfolds in America against the backdrop of the 1980s cultural era, although it does not demonstrate a positive example of the interaction of representatives of different nationalities and cultures in one social space, is still a means of cultivating multicultural values and tolerant attitudes towards one another, regardless of ethnic, racial or religious affiliation. The translation of Rainbow Rowell's book is very relevant to Ukrainian readers, since we lack Ukrainian original texts on similar topics. The modern Ukrainian children's book does not actually promote the culture of attitudes towards national minorities living in Ukraine. Writers do not artistically conceive patterns of behavior that would show how important it is for each child to feel "as a relationship with his family, and a genuine union with the community in which he died. A young citizen of the newest Ukraine may be an ethnic Korean or a Polish, Greek or Roman, a Hungarian or Russian, etc., the family can associate him with a certain religion, native language. But every child in Ukraine is equal with all other constitutional rights, and nobody, even a family, cannot deprive her/him of the right to knowledge of the state language, to a good future in the native country!" [10]. It is a twoway process of interaction between national cultures, common communication, socialization in which multiculturalism acts as an ethno-cultural dialogue in solving regional problems. There are several factors and main reasons for not depicting such important for the socialization of young people problems in the Ukrainian literature for children. Firstly, for decades, ideological Soviet literature was dampening national markers, promoting upbringing of a citizen of the USSR within the framework of the policy of a "melting pot" or the construction of a "new community of Soviet people" [4, p.19], but at the same time mercilessly criticizing "bourgeois society" from its democratic priorities. Secondly, the writers are not ready to engage in such com plex topics and speak them out at the level of conversation with the child, in the language, through the prism of their vision, at the level of their experience. Thirdly, only being a representative of a national minority or having one's own experience of staying in a multicultural, multi-ethnic environment, the author truly feels and experiences, and thus artistically reproduces the problem, deeply transmits the psychology of the child-hero, who appears and functions in such a space.

However, today in the educational policy of the state and in the literature for children and youth, we observe a tendency to be interested in the problems of multicultural discourse and national identity.

\section{CONCLUSIONS}

Modern literature for children and youth is one of the most effective means of multiculturalism as a promising direction for educational policy. Upbringing of citizenship, tolerance becomes especially relevant in the process of globalization, migration processes, polyethnicity, which is characteristic not only for the United States or developed European countries, but also for other states. It is a book for children and youth at the level of family education, school education, which can influence the formation of personality, give behavioral patterns that will determine the future life position. More detailed analysis of the stories of the Ukrainian writer Oksana Lushchevska ("Friends by Correspondence", "The Other House") and the American novel Rainbow Rowell "Eleonor and Park" testify to various examples of artistic coverage of intercultural interaction, the model of the socialization of the young personality in the multicultural space. Subject, plots, heroes, language are those components of the receptive poetics of the text, which provide an emotional impact on the reader and are translators of multicultural values. Analysis of other artistic texts using the tools of a multicultural approach, as well as a separate intelligence devoted to the methodological aspects of the implementation of the formula of multiculturalism in modern education in general and in the process of children's reading and studying literature in particular are the issues for our further research works. 


\section{REFERENCES}

[1] Drozhzhina S. Multiculturalism: theoretical and practical aspects. Political Management, 3 (2008), 96-106. Available at: http://nbuv.gov.ua/UJRN/PoMe_2008_3_11. (in Ukrainian)

[2] Educational programs. Through content lines. Ministry of Education and Science of Ukraine. Available at: https://mon.gov.ua/ua/osvita/zagalna-serednya-osvita/navchalni-programi/naskrizni-zmistovi-liniyi. (in Ukrainian)

[3] Kachak T.B. Ukrainian literature for children and youth. Academic Center, Kyiv, 2016. (in Ukrainian)

[4] Kalakura O.Y. Multiculturalism: the essence and prospects for Ukraine. Chronicle of Chornomorsk, 2 (2010), 19-25. (in Ukrainian)

[5] Kozlovets M.A., Mykhailova M.O. Multiculturalism and the problem of the unity of society. XX century - ethno-national dimension and Holocaust problems: a collection of scientific works based on the materials of international scientific and practical Conference, Zhytomyr, October 22-23, View of the Tkuma Center, Dnipropetrovsk, 2011, 463-472. (in Ukrainian)

[6] Law of Ukraine on Education. Available at: http://zakon2.rada.gov.ua/laws/show/2145-19. (in Ukrainian)

[7] Lushchevska O.P. Friends by correspondence. Publishing House Starogo Leva, Lviv, 2012. (in Ukrainian)

[8] Lushchevska O.P. Another House. Publishing House Starogo Leva, Lviv, 2013. (in Ukrainian)

[9] Lushchevska O.P. About Key Studies Studios on Children's Literature in the USA. Available at: http://www.chl.kiev.ua/key/Books/ShowBook/127.

[10] Methodical seminar "Children's literature: traditions and heirs". Available at: http://www.radaspilnot.org.ua/metodichnij-seminar-dityacha-literatura-tradicii-ta-spadkoyemci.

[11] Ukrainian language for general education institutions with Ukrainian language learning. Educational program (grades 5-9). Ministry of Education and Science of Ukraine. Available at http://old.mon.gov.ua/ua/activity/education/56/692/educational_programs/1349869088. (in Ukrainian)

[12] Vzdulskaya V. Intercultural interaction as a topic in contemporary Ukrainian children's prose. Available at: http://www.chl.kiev.ua/key/Books/ShowBook/93. (in Ukrainian)

[13] Zhyzhek S. Anxious subject: missing center of political ontology. PPP, Kyiv, 2008. (in Ukrainian)

[14] Hade Daniel D. Reading multiculturally. In: Harris V.J. (Eds.) Using multicultural children's literature in the K-8 classroom, (1997), 233-256. Available at: https://led6310summer2010.wikispaces.com/file/ view/Hade_+Multicultural.pdf.

[15] Rowell R. Eleanor and Park. Vivat, Kharkiv, 2016. (in Ukrainian)

[16] Ronan de Codiac. Multiculturalism. Available at: http://ethno-photo.livejournal.com/15997.html.

Address: Tetiana Kachak, Tetyana Blyznyuk, Vasyl Stefanyk Precarpathian National University, 57, Shevchenko Str., Ivano-Frankivsk, 76018, Ukraine.

E-mail: tetiana.kachak@gmail.com; blyztan@yahoo.com.

Received: 14.12.2017; revised: 06.03.2018.

Качак Тетяна, Бдизнюк Тетяна. Сучасна українська дітература для дітей та юнацтва у контексті мультикультуралізму як освітньої практики. Журнал Прикарпатського університету імені Василя Стефаника, 5 (1) (2018), 128-135.

У статті окреслено проблему актуальності мультикультуралізму в українському суспільстві й освітній практиці сучасної школи. Автори аналізують адресовані юним читачам художні твори Оксани Аущевської, які репрезентують співіснування різних форм культурного життя, висвітлюють проблему збереження власної й сприйняття іншої культурної ідентичності, тодерантної взаємодії 
представників різних етносів. Паралельно розглянуто роман американської письменниці Рейнбоу Ровелл, яка зосередила свою увагу на негативних явищах міжнаціональної взаємодії, але запропонувала читачам цікавий та багатофункціональний у плані рецептивної поетики та естетики художній текст. Представлені твори, на думку авторів, можуть бути ефективним засобом мультикультурного навчання й виховання школярів.

Ключові слова: література для дітей та юнацтва, мультикультуралізм, мультикультурна освіта, взаємодія культур. 